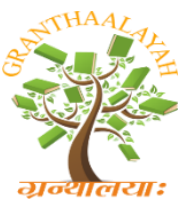

INTERNATIONAL JOURNAL OF RESEARCH GRANTHAALAYAH A knowledge Repository

Management

\title{
ASSESSING BUSINESS PROCESS RE-ENGINEERING IN PUBLIC SECTOR BANKS THROUGH AN ANALYSIS OF ATM TRANSACTIONS
}

\author{
Devendra Swami ${ }^{1}$, Shankar Chakraborty ${ }^{2}$, Meenakshi Sinha Swami ${ }^{* 3}$ \\ ${ }^{1}$ Head, State Bank of India, Lead Bank, Tehri Garwal, Uttarakhand, India \\ ${ }^{2}$ Chief Manager (Faculty), State Bank Learning Centre, Noida, India \\ *3 Assistant Professor, Department of Economics, Mata Sundari College for Women, University \\ of Delhi, New Delhi, India
}

DOI: https://doi.org/10.5281/zenodo.221660

\begin{abstract}
Business Process Re-engineering (BPR) technique implements organizational change based on the close coordination of a methodology for rapid change, employee empowerment and training and support through information technology. Alternate Delivery Channels are a part of BPR in public and private sector banks in India and includes ATMs, Automated Cheque Deposit Machines, Green Channel Counter Machines (GCCs), Cash Deposit Machines (CDMs) and Barcode Passbook Printers. ATM cash dispensing machines have revolutionised the very concept of money withdrawal. This research paper tries to compare the cost of routine manual banking transaction with the ATM transaction through cost-benefit analysis with the objective of finding out advantages of promoting ATM usage and migrating more and more customers to the ATM channel. ATM transactions have been on the rise easing the process of withdrawal and transfer of money for the common man. This has also been of help to the banking service providers, connected customers and efficient payment for the sellers of goods and services as ATM machines have come up close to markets.
\end{abstract}

Keywords: ATMs; Banks; BPR; Cost-Benefit Analysis; India.

Cite This Article: Devendra Swami, Shankar Chakraborty, and Meenakshi Sinha Swami. (2016). "ASSESSING BUSINESS PROCESS RE-ENGINEERING IN PUBLIC SECTOR BANKS THROUGH AN ANALYSIS OF ATM TRANSACTIONS." International Journal of Research Granthaalayah, 4(12), 72-78. https://doi.org/10.5281/zenodo.221660.

\section{Introduction}

Banks in India have planned to transform themselves into world class financial institutions proactively reaching out to acquire new quality customers, building deep and lasting relationships with existing customers and providing all customers with the best quality of service across multiple channels. 
Like in most banks, BPR project in major public sector banks which align it with ATMs, aims to place the customer at the center of the business, to acquire new quality customers, to provide customers the best quality of service across multiple channels according to the environment and expectation of customers, to build deep and lasting relationship with customers, to improve productivity through increase of business and profit per employee, free up time of Branch and Branch Manager to focus on sales and marketing and keep pace with technological changes.

ATM machines are coming up at a fast rate to the joy of customers and at the same time are being critically looked at due to multiple ATM's in one location, leading to wastage of resources. The paper tries to justify the role of ATM's in the present scenario over manual transactions through a cost benefit analysis.

The paper analysis the ATM transaction of a major public sector bank and analysis the data to draw conclusions. The results strongly point to the positive aspects of BPR through ATM transactions highlighting its cost cutting nature.

\section{Review of Literature}

There is a fundamental transformation occurring in business - in terms of its structure, processes, people, and technology through BPR.

Business Process Re-engineering (BPR) involves the redrawing of organizational boundaries, the reconsideration of jobs, tasks, and skills by rearchitecting of business and management processes. This occurs with the creation and the use of models. More specifically, BPR is defined as the use of scientific methods, models and tools to bring about the radical restructuring of an enterprise that result in significant improvements in performance (Zigiaris, 2000) ${ }^{1,2}$ Business Process Reengineering breaks down activities into processes instead of structures to achieve organisation desired objectives (Cheng, Tsai \& Xiano, 2006) ${ }^{3}$. Herzog, Polajnar \& Tonchia, $(2007)^{4}$ defined business process reengineering as a management discipline for analyzing and redesigning current business processes and their components in terms of efficiency, effectiveness and added value to the objectives of the business.

Datta and Kundu (2011) ${ }^{5}$ discuss about e-banking initiatives in Indian public sector banks (PSBs) and considered it as a successful case of BPR implementation. A recent study by Kumar and Mishra $(2014)^{6}$ has revealed that BPR in four branches of SBI has resulted into radical improvements like reduction in operational costs, improvement in quality of products and services, speed of the banking transactions has improved, day to day banking transactions has become more convenient and organizational culture of all four branches has improved.

ATMs were introduced in 1990 in India, but their coverage has been visible only since 1998 due to both a fall in the price of ATMs and an increase in the wage bill for tellers contributing to the diffusion of the ATMs (Kumar, Malathy \& Ganesh) ${ }^{7}$. ATM Channel has dominated the public technology segment, and future of ATM industry is also quite bright in India. (Hota, 2013) ${ }^{8}$. Banks since the last decade and a half have been providing more facilities through ATMs, Ibanking, Tele-banking etc. ATM is one of the best alternative and most popular e-channel available to customers for quick, correct and efficient service at anytime and anywhere (Uppal, 
2010) $)^{9}$. Cash availability and transaction speed are found to have a strong influence on customer satisfaction of ATMs (Kumar, Varaprasad et el, 2013) ${ }^{10}$ Easy availability of machines also affects its use. Customer uses ATM because they agree that its use is secure. ATMs are presently being increasingly used (Giri, Choudhary \& Verma, 2014) ${ }^{11}$,

An understanding of cultural biases and metaphors can facilitate technology diffusion and acceptance informing design localisation and supporting the development of strategies to motivate and train users. (Anjelia et al, 2004) ${ }^{12}$

\section{Objective of the Study}

The study was undertaken with an objective to find out if the costs undertaken by banks for Business Process Re-engineering are justified. The objective of this study in particular is to study the ATM organization and find the benefit of ATM transactions over manual transactions for the public sector banks through cost-benefit analysis. Comparison was undertaken to find out the advantages of promoting ATM usage and migrating more and more customers to the ATM channel.

\section{Data and Research Methodology}

ATM organization details have been sourced from public sector bank manuals. Primary and secondary data for cost-benefit analysis has been sourced from State Bank of India's branches in Delhi. The period of data collection was 2014-2015 and the data is of the year 2013-2014

\section{ATM Organization in a Public Sector Bank}

ATM organization has been set up in most public sector banks. State Bank of India, the largest public sector bank in India has a Project based ATM organization which has been set up at all Circles and Corporate Center. A 'strategy' group and 'operations and project management' group has been created for its functioning. The strategy group is responsible for density and locational decisions, migration strategies, vendor tie-ups and performance monitoring of ATMs.

For the Bank, migrating customers to ATMs results in reduced transaction costs and free time for staff to pursue value added activities, which is the core theme under BPR. To achieve this, ensuring fail safe functioning of ATMs is a prerequisite.

\section{Cost-Benefit Analysis}

A large public sector branch in Model Town in Delhi under State Bank of India was selected for the data. Cost-benefit analysis has been used to work out the cost of one routine manual banking transaction and one ATM transaction and compare these in order to evaluate the benefit of migrating customers to ATMs. Hence, all items of cost at the branch were scrupulously ascertained from the branch data, viz. rent and taxes, salaries and allowances, electricity charges, and so on (individual items are given in the table no. 1 below). Thereafter, data on total manual transactions for a month and number of staff members was collected and thus cost of single manual transaction was worked out as detailed in the table no. 2. Similarly, individual items of 
cost for running ATM (given in the table no. 3 below) were also ascertained from the branch as the ATM was an on-site ATM and entire expenses of running the ATM site were borne by the said branch and thus the cost of a single ATM transaction was worked out (table no. 4). The costs of a manual transaction and an ATM transaction were then compared as under.

\section{Comparison of Cost of a Manual Transaction vis-à-vis an ATM Transaction of a typical BPR branch}

The comparison was made possible with the help of data on Staff and Overheads costs of a Typical BPR Branch and cost of an ATM Transaction. The four tables given below detail the data collected and show the procedure of computation.

Table 1: Staff and Overheads Data of a Typical BPR Branch

\begin{tabular}{|l|l|l|l|}
\hline \multicolumn{1}{|c|}{ Particulars } & No. & $\begin{array}{c}\text { Operating Costs } \\
\text { (Rs. In } \\
\text { Thousands) } \\
\text { year 2013-2014 }\end{array}$ & $\begin{array}{c}\text { Operating Cost } \\
\text { per Teller Per } \\
\text { month (Rs. In } \\
\text { thousands) }\end{array}$ \\
\hline & (A) & \multicolumn{1}{c|}{ (B) } & (B/A)/12 \\
\hline $\begin{array}{l}\text { No. of Transaction Tellers } \\
\text { (staff }\end{array}$ & 19 & & 52.26 \\
\hline $\begin{array}{l}\text { Salary \& Allowances } \\
\text { including D. A. }\end{array}$ & & 11916 & 19.05 \\
\hline $\begin{array}{l}\text { Staff Expenses- Other than } \\
\text { Salary \& Allowances }\end{array}$ & & 4344 & 18.03 \\
\hline Overheads & & 4112 & 0.61 \\
\hline Rent and taxes & 139 & 4.40 \\
\hline Telephones & & 1004 & 3.06 \\
\hline Electricity and gas charges & 698 & 1.90 \\
\hline Depreciation & & 436 & 1.00 \\
\hline Hiring of Services & 226 & 1.87 \\
\hline Repairs and Maintenance & 426 & 0.82 \\
\hline Stationery & 188 & 2.78 \\
\hline Halting Allowance & 634 & 1.25 \\
\hline Travelling Expenses & 285 & $107.35(\mathrm{C})$ \\
\hline Miscellaneous Expenses & 24408 & \\
\hline \multicolumn{1}{|c|}{ TOTAL } & & & \\
\hline
\end{tabular}

* Rs. $1,07,350=00$

The comparison of a manual transaction with an ATM transaction was possible with the data collected for the two in the following manner. 
Table 2: Cost of a Manual Transaction

\begin{tabular}{|l|l|}
\hline \multicolumn{2}{|c|}{ Cost of a Manual Transaction for the year 2013-2014 } \\
\hline $\begin{array}{l}\text { No. of working days per month excluding } \\
\text { Sundays and Holidays on an average }\end{array}$ & 25 \\
\hline $\begin{array}{l}\text { Less - On an average 1 Casual and 2 Earned } \\
\text { Leaves availed by staff }\end{array}$ & 3 \\
\hline $\begin{array}{l}\text { Hence, on an average no. of days branch } \\
\text { attended by staff }\end{array}$ & 22 \\
\hline No. of Transactions per teller per day & 100 \\
\hline $\begin{array}{l}\text { No. of Transaction per teller in a month } \\
(22 * 100)\end{array}$ & 2200 (D) \\
\hline $\begin{array}{l}\text { Hence, cost of a manual transaction (cash } \\
\text { withdrawal, etc) }\end{array}$ & $\begin{array}{r}\text { C)/(D) }=\text { Rs. } 1,07,350 / 2200 \\
\text { = Rs. 48.79 per transaction }\end{array}$ \\
\hline
\end{tabular}

The cost of manual transaction was carried out by dividing the figure (C) in table 1 which represents operating cost per teller per month in rupees with figure (D) in table 2 which represents cost of a manual transaction (cash withdrawal, etc).

Table 3: Cost of an ATM Transaction at the On-Site ATM

\begin{tabular}{|l|l|l|}
\hline \multicolumn{2}{|c|}{ Cost of an ATM Transaction at the on-site ATM onsite 2013-2014 } \\
\hline \multicolumn{1}{|c|}{ Item of Cost } & $\begin{array}{l}\text { Cost (Rs. } \\
\text { Per Month) }\end{array}$ & \multicolumn{1}{c|}{ Remarks } \\
\hline Rent of the ATM room & 22,000 & $\begin{array}{l}\text { An 8 feet by 7 feet room having a partitioned } \\
\text { backroom also. }\end{array}$ \\
\hline Electricity & 16,000 & has a separate electricity meter \\
\hline Depreciation & 5,952 & $\begin{array}{l}\text { Cost of ATM and UPS = Rs. 5,00,000=00 } \\
\text { depreciated by about 15 per cent per year } \\
\text { through straight line method }\end{array}$ \\
\hline $\begin{array}{l}\text { Annual Maintenance } \\
\text { Contract of ATM system }\end{array}$ & 2,500 & Includes preventive maintenance also. \\
\hline Insurance & 835 & $\begin{array}{l}\text { For all risks for the equipments arranged by } \\
\text { Corporate Centre }\end{array}$ \\
\hline Security Guards & 4,500 & 3 security guards for 3 shifts each 8 hours \\
\hline Communication & 10,000 & $\begin{array}{l}\text { Through the dedicated data circuit leased line of } \\
\text { MTNL of the branch and also standby line ISDN } \\
\text { of Airtel in case of disruption of the leased line }\end{array}$ \\
\hline Stationery & 1,000 & Include paper roll for the receipt printer \\
\hline Repairs/ Spares & 2,500 & $\begin{array}{l}\text { Electrical and civil repairs and chargeable } \\
\text { repairs of the ATM not covered under AMC. }\end{array}$ \\
\hline Batteries & 2,888 & $\begin{array}{l}8 \text { batteries costing approx Rs. 1,00,000=00 } \\
\text { lasting for about 3 years. }\end{array}$ \\
\hline $\begin{array}{l}\text { Apportioned } \\
\text { expenses }\end{array}$ & $\begin{array}{l}\text { 2 staff members as ATM joint custodians for } \\
\text { cash replenishment, attending cash dispenser } \\
\text { faults and currency preparation and ATM related } \\
\text { reconciliation work }\end{array}$ \\
\hline
\end{tabular}




\begin{tabular}{|llr|l|l|}
\hline $\begin{array}{l}\text { Total Expenses per } \\
\text { month }\end{array}$ & $\begin{array}{l}78,175 \\
\text { (A) }\end{array}$ & \\
\hline
\end{tabular}

Monthly cost of ATM Transaction at the on-site ATM is represented by (A) in table 3, and the cost of a single ATM Transaction at the on-site ATM is calculated by dividing (A) with (B) which represents the total number of transactions on the ATM per month

Table 4: Computation of the Cost of an ATM Transaction

\begin{tabular}{|l|l|l|}
\hline \multicolumn{2}{|c|}{ Computation of the cost of an ATM Transaction } \\
\hline \multicolumn{1}{|c|}{ Particulars } & \multicolumn{1}{c|}{ Value (no./ Rs.) } & Remarks \\
\hline $\begin{array}{l}\text { Average no. of ATM } \\
\text { transactions per day }\end{array}$ & $\begin{array}{l}\text { Scaleable to more transactions } \\
\text { per day - upto 500 transactions } \\
\text { per day }\end{array}$ \\
\hline $\begin{array}{l}\text { Total no. of transactions on } \\
\text { the ATM per month }\end{array}$ & $\begin{array}{l}150 * 30= \\
4500(\mathrm{~B})\end{array}$ & \\
\hline $\begin{array}{l}\text { Cost of a single ATM } \\
\text { Transaction }\end{array}$ & $\begin{array}{l}\text { Rs. } 17.37(\mathrm{~A} / \mathrm{B}) \\
\text { (Rs. 78,175/450) }\end{array}$ & \\
\hline
\end{tabular}

\section{Interpretation}

It can be seen from the above computations, referring to Table 1 and Table 2 that Cost of a manual transaction works out to Rs. 48.79, whereas that of an ATM transaction works out to Rs. 17.37 per transaction (Table 3 and table 4). In addition to it, even at an average level of 150 transactions per day (scalable to even more number of transactions), an ATM processes 4500 transactions in a month compared to about 2200 transactions handled by a manual teller.

Therefore,

Cost of 4500 manual transactions in a month by manual tellers $=4500 * 48.79=$

Rs. $2,19,555=00$

Cost of 4500 ATM transactions in month $=4500 * 17.37=$

Rs. $78,165=00$

Difference $=$ Rs. 1, 41,390=00. Hence, installing one ATM can impart an incremental benefit Rs. $1,41,390=00$ per month for the branch,

This is roughly equivalent to replacing two manual tellers by a single ATM.

\section{Conclusion and Recommendation}

Since installing one ATM can impart an incremental benefit Rs. 1,41,390=00 per month for the branch, which is roughly replacing two manual tellers by a single ATM. It can therefore be concluded that a significant amount of cost reduction is feasible through automating the processes under BPR. 
ATMs have become a crucial part of banking service in India and it will be beneficial to migrate more and more customers to these machines. Therefore banks should increasingly make use of these machines for mutual benefit, for banks as well as of the customers. This will require placing ATMs at points of easy access and near market hubs, apart from making them safe and secure. Customers should also be made aware of the easy access through these machines by installing them at bank branch campus with facilities of guidance to new ATM users.

\section{References}

[1] Zigiaris, Sotiris., (2000), Business Process Re-Engineering BPR, BPR Hellas, SA, Report funded by EC, IINNORGIO Project, p1-24.

[2] Hammer, M., Champy, J., (1993), Reengineering the Corporation: A Manifesto for Business Revolution. Harper Business, New York.

[3] Cheng, T. C. E., \& Chiu, Ida S. F., (2008), Critical Success Factors of Business Process Re Engineering in The Banking Industry, Knowledge and Process Management, Volume 15, Issue 4, October, p 258-269 http://onlinelibrary.wiley.com/doi/10.1002/kpm.316/abstract.

[4] Herzog, N., Polajnar, A., \& Tonchia, S. (2007). Development and Validation of Business Process Reengineering (BPR) Variables; A Survey Research in Slovenian Companies. International Journal of Production Research, 45(24), p 5811-5834. http://dx.doi.org/10.1080/00207540600854992.

[5] Datta, S. K.\& Kundu, S., E-banking" initiatives in Indian banks : a case of business process reengineering (BPR) implementation, World Review of Entrepreneurship, Management and Sustainable Development, Inderscience Enterprises, ISSN 1746-0573, ZDB-ID 21933820. - Vol. 7.2011, 2, p. 174-191.

[6] Kumar, S., \& Mishra, K (2014) Business Process Reengineering (BPR): An Empirical Study on State Bank of India, International Journal of Engineering and Management Research, Volume 4, Issue 2, April 2014, p95-99.

[7] Kumar, Lakshmi., Malathy, D., \&. Ganesh, L.S. (2011) "The diffusion of ATM technology in Indian banking", Journal of Economic Studies, Vol. 38 Iss: 4, pp.483 - 500, Emerald Publishing Group.

[8] Hota, Jyotiranjan (2013) Growth of ATM Industry in India, CSI Communications , 02/2013; 36(11):23-25, Research Gate, assessed on 21/12/2015, https://www.researchgate.net/publication/235436177_Growth_of_ATM_Industry_in_India

[9] Uppal, R.K. (2010), Future Outlook of ATMs in India - Emerging Issues and Possible Solutions, Volume 4, Issue 12, December 2010, Indian Journal of Finance, p 3-12, DOI: 10.17010/ijf/2010/v4i12/72548.

[10] Kumar, R. M., Varaprasad, G., Sridharan, R., \& Unnithan, A. B. (2013). An Empirical Study to Identify the Factors Influencing the Customer Satisfaction of ATMs in India. International Journal of Strategic Decision Sciences (IJSDS), 4(4), 25-40. doi:10.4018/ijsds.2013100102.

[11] Giri, S., Choudhary S. \& Verma, R. (2014), A Comparative Study of an Automatic Teller Machine (ATM), Indian Streams Research Journal. 2014;4(8)1-14, Laxmi Book Publication, India.

[12] Anjelia A.D., Athavankarb, U., Joshib, A., Coventyra, L. \& Johnsona, G.I. (2004) Introducing ATMs in India: a contextual inquiry, Interacting with Computers, Volume 16, issue 1, Oxford Journals, p 29-44. doi: 10.1016/j.intcom.2003.11.003.

\footnotetext{
*Corresponding author.

E-mail address: meenakshi.sinhaswami@gmail.com
} 